\title{
A Post-Implementation Analysis Of The South African Mineral Royalty Regime
}

Pieter van der Zwan, North-West University, South Africa

\begin{abstract}
The landscape of the South African mining industry has changed significantly over the past twenty years and has in recent times attracted attention by calls for nationalization of the industry. One of the proposed areas to address the concerns resulting in these calls for nationalization has been to consider whether the South African mineral royalty regime can be improved. The objective of this article is to evaluate whether the South African royalty regime effectively balances the objectives of the stakeholders in the industry and to recommend improvements where this balance may not be achieved. The analysis performed indicated that the introduction of the royalty regime increased the overall government take from the mining industry significantly and that the competitiveness of the South African mining industry as an investment destination need to be assessed. It was further found that the linkage between the royalty formula and the income tax legislation distorts the royalty levied in relation to the mineral resources that are depleted. It is submitted that the regime can be improved by defining a profitability indicator specifically for the purposes of determining mineral royalties. Lastly, it is recommended that measures to improve accountability in respect of the utilization of the royalties collected need to be considered as the lack of such measures may contribute to the perception that the nation does not receive its fair share of the mineral wealth.
\end{abstract}

Keywords: Mineral and Petroleum Resources Royalty Act; South African Mineral Royalties

\section{BACKGROUND}

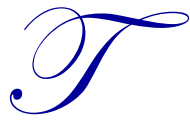

he landscape within which mining companies operate in South Africa has changed significantly over the period since 1994 when the African National Congress (ANC) came to power in the country's first democratic election. The reformulation of the country's mineral policies included the enactment of the Mineral and Petroleum Resources Development Act (Act 28 of 2002) (hereafter referred to as 'MPRDA') (South Africa, 2002). One of the main objects in section 2 of this legislation is to recognize the internationally accepted right of the State to exercise sovereignty over all the mineral and petroleum resources within South Africa. To achieve this shift from a system where private ownership of mineral resources was possible in accordance with the Minerals Act (50 of 1991) (Cawood \& Minnitt, 1998), section 3 of the MPRDA determines that the mineral and petroleum resources of the country are the common heritage of the people of South Africa and that the State acts as custodian thereof for the benefit of all South Africans. In its role as custodian over the nation's mineral and petroleum resources, section 3(2) of the MPRDA allows the State, in consultation with the Minister of Finance, to determine and levy any fee or consideration payable in terms of any Act in respect of these mineral and petroleum resources. The Mineral and Petroleum Resources Royalty Act (28 of 2008) (hereafter referred to as 'MPRRA'), which became effective from March 2010, was enacted to give effect to section 3(2) of the MPRDA. This legislation, which imposes a royalty on the transfer of mineral resources by a person who extracted it from within South Africa (South Africa, 2008) is the subject of the research that this article reports on.

The recognition of the State's sovereignty over the nation's mineral and petroleum resources is however accompanied by the responsibility of the State to ensure the sustainable development of South Africa's mineral and petroleum resources within a framework of national environmental policy, norms and standards while promoting economic and social development. Due to South Africa's history of apartheid, sections 2(d) and (f) of the MPRDA specifically mention that the legislation aims to "substantially and meaningfully expand opportunities for historically 
disadvantaged persons, including women, to enter the mineral and petroleum industries and to benefit from the exploitation of the nation's mineral and petroleum resources" and to "promote employment and advance the social and economic welfare of all South Africans".

Since 2010, the topic of nationalization of the South African mining industry has been raised and considered on a number of occasions. In a discussion document issued during February 2010, the ANC Youth League ${ }^{1}$ (hereafter referred to as "ANCYL"), indicated that nationalization of the mining industry in South Africa is necessary to achieve the objective contained in the Freedom Charter, ${ }^{2}$ namely that the people as a whole should share in the country's mineral wealth (ANCYL, 2010). The nationalization debate centered on suggestions that the country's mineral wealth is not utilized to advance the social and economic welfare of all South Africans as intended by the MPRDA. The nationalization deliberations culminated in the publication of a report on the State Intervention in the Mining Sector (the so-called SIMS Report) in 2012. This report acknowledges that the State's objective of investing and sharing the wealth with the nation as a whole remains a challenge that needs to be addressed. The report however concludes that nationalization of the mining industry is not necessarily the appropriate measure to address this challenge and instead proposes an alternative solution to the problem. This solution includes an indication that the State may not be receiving its fair share of the resource rents from the extraction of the nation's mineral wealth. One component of the proposal in the SIMS Report is therefore aimed at ensuring that fiscal instruments are implemented to capture a fair share of the resource rents from the extraction of the nation's mineral resources. In this regard, the main proposal is the introduction of a resource rent tax in South Africa (ANC, 2012). The National Planning Minister, Trevor Manuel, was however of the view that improvements to the royalty regime established by the MPRRA may be preferable to the introduction of a new more radical tax, such as a resource rent tax, in the mining industry (Reuters, 2012). The Minister of Mineral Resources, Susan Shabangu, was similarly opposed to the introduction of resource rent taxes as proposed in the SIMS report (Janse van Vuuren, 2012).

\section{PROBLEM STATEMENT AND OBJECTIVES}

The problem statement addressed by this study is that the current mineral royalty regime may not contribute sufficiently to ensure that the State receives a fair share of the wealth of South Africa's mineral resources. This problem statement is supported by the views of policymakers in South Africa that the royalty regime can be improved to address the concerns that gave rise to the nationalization debate in the South African mining industry.

The research question that this study aims to answer is whether the mineral royalty regime imposed by the MPRRA strikes an effective balance between the objectives of the relevant stakeholders in the South African mining industry?

In order to answer this research question, the following research objectives have been formulated:

- $\quad$ to identify the stakeholders in the South African mining industry and their objectives that must be taken into account when designing and evaluating a mineral royalty regime;

- $\quad$ to evaluate whether the current mineral royalty regime imposed in terms of the MPRRA balances the objectives of the relevant stakeholders identified in the first objective and to contribute to the continued development of the South African royalty regime by making recommendations as to aspects of the regime that can be improved.

\footnotetext{
${ }^{1}$ The ANCYL is an organization of the youth governed by and which adheres to the policies and programmes of the ANC. The existence of this organization is derived from the Constitution of the ANC (ANCYL, 2011).

2 The Freedom Charter is the statement of core principles of the South African Congress Alliance, which consisted of the African National Congress and its allies the South African Indian Congress, the South African Congress of Democrats and the Colored People's Congress. This statement was adopted at the Congress of the People in Kliptown on 26 June 1955.
}

642 Copyright by author(s) $\underline{\text { Creative Commons License CC-BY }}$

2013 The Clute Institute 


\section{STAKEHOLDERS IN THE MINING INDUSTRY AND THEIR OBJECTIVES}

\section{A brief overview of the theory of mineral royalties}

Otto et al. (2006) describe a mineral royalty as an instrument that enables payment of compensation by an extractor of a mineral resource to the owner in exchange for granting permission to access and develop the mineral resource for its own benefit. Cawood (2010) states that royalties are the sum of cash and other benefits received by the owner of a mineral resource when the resource is used and ownership is transferred to another party. Otto et al. (2006) confirms that a royalty payment would in effect be an ownership transfer tax. The imposition of mineral royalties is further justified by an argument that the royalties constitute payment to the owner of the mineral resource for the fact that a non-renewable resource is being depleted (van der Zwan \& Nel, 2010).

Otto and Cordes (2002) are of the view that a mineral royalty also represent an instrument that balances the risks involved in developing the mineral resource between the investor (mining company) and the owner of the mineral resource, which is often the State. As a royalty constitutes an instrument that can be used to balance the risk relating to the mineral resource between the owner and the extractor, this instrument can be used to ensure that the owner captures a fair share rent derived from the mineral resources (Tilton, 2004). Given this purposes of the royalty as a fiscal instrument, Otto et al. (2006) indicate that in cases where ownership of a country's mineral wealth is vested in the State, mineral royalties are often used as instruments that can bring about socioeconomic changes using its share of rents collected.

\section{Objectives of the stakeholders}

Based on the above discussion of the theory underpinning mineral royalties a number of parties who are stakeholders affected by the imposition and design of a royalty regime can be identified. Firstly, the owner of the mineral resources, which in the South African context is the State as custodian of the nation's mineral resources, who receives the royalty as compensation for the depletion of its mineral resources will have an interest in the royalties imposed. Secondly, the investor or mining company extracting the mineral resources, who would be the party paying the mineral royalties, has a stake in the regime. Lastly, the nation on whose behalf the State acts as custodian over the resources and whose welfare the State has to advance and promote according to the MPRDA, has an interest, albeit an indirect interest, in a royalty regime.

The particular objectives of each of the stakeholders will be investigated in order to evaluate whether the royalty regime imposed by the MPRRA effectively balances the objectives of each of these stakeholders.

\section{State as custodian of the nation's mineral resources}

The objective of the State, as laid down by section 3 of the MPRDA, is first and foremost to ensure the sustainable development of South Africa's mineral and petroleum resources within a framework of national environmental policy, norms and standards while promoting economic and social development. In order to be able to do this, the State has to collect a sufficient share of the resource rents to enable it to achieve its social and economic objectives (Sharma \& Naresh, 2001). This however involves a fine balancing act between ensuring that the State collects sufficient compensation, even though it may often be at a disadvantage as to information about mineral reserves which is held by private extractors (Osmundsen, 1998), while at the same time being cautious of the fact that the rent should not be excessive as this will discourage mining companies from investing in the development of a country's mineral resources, which could ultimately result in the mineral resources not being developed and the nation not enjoying the benefits of the mineral resources (Otto et al., 2006). The mining industry provides an opportunity for a country to lure foreign direct investment. A mineral royalty regime should therefore furthermore strike a balance between creating a tax regime that is able to attract foreign investment to the South African mining industry but at the same time prevent its mineral wealth being stripped by foreign investors before the country has collected its fair share of this wealth (Andrews-Speed \& Phillips, 1999). In order to evaluate this objective, the level of royalties imposed is analyzed from the perspective of the State. 
As custodian of the nation's mineral resources, the State has the responsibility of ensuring that the national wealth obtained from these non-renewable resources is maximized. The benefit derived from the exploration of the country's non-renewable mineral resources can among other be maximized when value is added by further refinement and processing (referred to as downstream beneficiation) before the resources are transferred (Department of Minerals \& Energy, 1998). A royalty regime should therefore provide encouragement for, or at the very least not discourage, extractors to engage in downstream beneficiation prior to exporting the mineral resources that have been extracted. This aspect is evaluated by considering the effect of refinement on the royalty charged.

\section{Mining industry as extractor of the mineral resources}

Companies investing in the mining industry are primarily driven by the motive to maximize profits and shareholder value. The overall tax charge, which royalties would form part of, will reduce the return earned by investors (Otto et al., 2006). In order to provide an acceptable return to attract investors, the South African tax regime must be competitive in comparison with those of other countries as geological potential of a project can be strongly offset by uncompetitive fiscal and regulatory consequences (Eads, Mitchell \& Paris, 2009). In addition to a tax regime that provides investors with an opportunity to earn an acceptable return on its investment, Eads, Mitchell \& Paris (2009) also state that tax stability plays an important role in the decision of to invest in a project to develop a mineral resource body. In order to evaluate this objective, the level of royalties imposed is analyzed from the perspective of its impact on the returns for investors.

\section{Nation and communities}

Societies expect that geological resources that belong to a nation will be transformed into tangible benefits for the community (Eads, Mitchell \& Paris, 2009). Communities in South Africa furthermore expect that the wealth generated from the country's mineral wealth will be used to remedy the inequalities of the apartheid era (Wälde, 2002). This objective of the nation and communities have been incorporated into the objects of the MRPDA that state that substantial and meaningful opportunities must be created and expanded for historically disadvantaged persons to enter the mineral and petroleum industries and to benefit from the exploitation of the nation's mineral and petroleum resources. The achievement of the objective of the nation and communities to participate in the country's mineral wealth is analyzed by considering the utilization of royalties collected.

\section{ANALYSIS OF THE SOUTH AFRICAN MINERAL ROYALTY REGIME}

\section{Overview of the main provisions of the MPRRA}

In terms of section 2 of the MPRRA, a person who extracts and transfers a mineral resource extracted from within South Africa is liable to pay a royalty. The royalty is determined as the gross sales value of the mineral resource at the time of transfer (tax basis) multiplied by a sliding royalty rate (tax rate), which is determined in terms of section 4 of the MPRRA. A distinction is made between refined and unrefined mineral resources transferred when calculating the royalties.

\section{Gross sales value as the tax basis}

Gross sales value is defined in section 6 of the MPRRA. In respect of a mineral resource transferred in the either the refined or unrefined condition specified in the schedules to the MPRRA, gross sales value means the amount received or accrued in respect of the transfer of the mineral resource. If however the mineral is not transferred in the condition specified in the schedules to the MPRRA, section 6 requires that the amount received must be adjusted upward or downward, depending on the condition in which the mineral is transferred, to an arm's length price if the mineral was transferred in a condition specified in the schedules. This adjustment has proven to be challenging in practice, in particular in respect of coal where various grades of coal can be transferred in the unrefined condition (Cawood, 2010). Section 11 of the MPRRA contains a wide ranging transfer pricing provision, that allows the Commissioner of the South African Revenue Services (SARS) to adjust the gross sales value from any transfer to reflect a gross sales value that would have been derived from a transaction entered into at arm's length if he is of the view that the gross sales value received or accrued differs from the arm's length amount. 
Sliding royalty rates

Section 4 of the MPRRA provides the following formulas to determine the royalty rates:

Royalty rate in respect of refined minerals $(\mathrm{s} 4(1)): 0.5+\left(\frac{\text { EBIT for refined minerals }}{\text { Gross sales of refined minerals } \times 12.5(\mathbf{B}-\text { factor })} \times 100\right)$

Royalty rate in respect of unrefined minerals $(\mathrm{s} 4(2)): 0.5+\left(\frac{\text { EBIT for unrefined minerals }}{\text { Gross sales of unrefined minerals } \mathrm{x} \text { (B-factor) }} \times 100\right)$

These formulas guarantee the State of a royalty of at least $0.5 \%$ of the gross sales value when a mineral resource is transferred, irrespective of the profitability of the extractor. The additional compensation for the State will depend on the ability of the extractor to pay the royalty from the profits realized from the mineral resource as the ratio of (EBIT/gross sales value) should reflect the profitability of the extractor.

For purposes of the royalty rate formulas, earnings before interest and tax (hereafter referred to as EBIT) is defined in section 5 of the MPRRA as the gross sales of the extractor in respect of minerals during a year of assessment less any amount that is deductible in terms of the Income Tax Act (58 of 1962) from the income of the extractor during such year of assessment in respect of assets used or expenditure incurred to win, recover and develop those mineral resources to the condition specified in the relevant schedule. It is important to note that this definition of EBIT clearly makes provision for a deduction of allowances granted in respect of capital assets used to win, recover and develop the mineral resources. During the process to draft the legislation, the legislator acknowledged that the mining process is capital intensive and that capital expenditure had to be taken into account in the royalty formulas. One of the main deductions relating to capital expenditure by mining companies in the Income Tax Act is section 36, which provides an accelerated allowance for capital expenditure, subject to certain ring-fencing rules. The royalty rates are capped at $5 \%$ for refined minerals and $7 \%$ for unrefined minerals.

\section{Analysis of the level of royalties collected}

\section{Comparison to the international norm}

When the final version of the MPRRA was promulgated National Treasury (2008c) indicated that the royalty rates, based on historical data on the profitability of the mining industry, were expected to range between $1 \%$ and $5 \%$, with an average of approximately 2,7\%. According to a study performed by Cawood and Macfarlane (2003), evidence suggested that the international norm for royalty rates ranged between $0 \%$ and $3 \%$ applied to a net smelter value, which is normally determined as the gross sales value reduced by expenditure incurred since extraction of the mineral resource. The expected royalty rate of between $1 \%$ and $5 \%$ applied to a gross sales value therefore appear relatively high at first glance in comparison to the international norm.

\section{Impact of royalties on profits and the effective tax rates of companies}

In a pre-implementation analysis of the royalty regime, Van der Zwan and Nel (2010) found that the overall level of the royalty was likely to reduce the net profits of a mining company extracting and transferring mineral resources in South Africa by between $10 \%$ and $13 \%$. This finding was supported by the following mathematical reworking of the royalty formulas:

$$
\begin{array}{r}
\begin{array}{r}
\text { Royalty }(\text { refined minerals })=\text { Gross sales }(S) \times\left[0.5 \%+\left(\frac{\text { EBIT }}{S \times(12.5)}\right) \times 100\right] \\
=(0.5 \% \times S)+\left(\text { EBIT } \times \frac{1}{12.5}\right) \times 100=(\mathbf{0 . 5} \% \times \text { S })+(\text { EBIT } \times 8 \%) \\
\text { Royalty (unrefined minerals })=\text { Gross sales }(S) \times\left[0.5 \%+\left(\frac{\text { EBIT }}{S \times(9)}\right) \times 100\right] \\
=(0.5 \% \times S)+\left(\text { EBIT } \times \frac{1}{12.5}\right) \times 100=(\mathbf{0 . 5} \% \times \text { S })+(\text { EBIT } \times 11.11 \%)
\end{array}
\end{array}
$$


A criticism against the level of royalties suggested by the re-worked formulas is that it does not recognize the impact of the cap on the royalty rates. The maximum rates of 5\% in respect of refined mineral resources and 7\% in respect of unrefined mineral resources will only be triggered if the net profit margin exceeds $56.25 \%$ in the case of refined minerals and $58.5 \%$ in the case of unrefined minerals, which are extremely high profit margins. This implies that the cap will only apply in extraordinary circumstances.

When evaluating the impact of the estimated level of royalties on a company's profit after tax it must be taken into account that companies operating in South Africa are subject to corporate income tax at a rate of $28 \%$ on their profits as well as an additional 15\% dividends tax if those profits are distributed to the shareholders of a company. Table 1 illustrates the effective tax rate of a company involved in the South African mining industry assuming that it only earns profits from extracting and selling mineral resources.

Table 1: Effective tax rate of a company involved in mining in South Africa

\begin{tabular}{|l|c|}
\hline Net profits before taxes & 100 \\
\hline Royalty tax imposed (at a rate of 10\%, which would be a conservative estimate based on the discussion above) & $(10)$ \\
\hline Net profit for income tax purposes 3 & 90 \\
\hline Corporate income tax at a rate of $28 \%$ & $(25,2)$ \\
\hline Net profits left for distribution to shareholders & 64,8 \\
\hline Dividends tax at a rate of 15\% if these profits are distributed & $(9,72)$ \\
\hline Profit remaining after royalty tax, corporate income tax and dividends tax & 55,08 \\
\hline
\end{tabular}

The effective tax rate of companies that are not subject to the royalties in terms of the MPRRA in South Africa is $38.8 \%$. The royalty regime therefore increases the overall tax burden of a mining company by $15,8 \%$ to $44,92 \%$. It is submitted that the effect of the royalty on the State's take from the mining industry is therefore relatively high. Based on this finding, it is recommended that a study should be performed to compare the South African government take in respect of mining operations to that of countries with similar mineral resource wealth.

\section{Linkage of the royalty regime to the income tax legislation}

The indication of the expected royalty rates by National Treasury (2008c) as well as the analysis performed by van der Zwan and Nel (2010) evaluated the impact of the royalties within the context of EBIT as an accounting indicator of profits. The impact of the linkage between the royalty formulas and income tax legislation, in particular section 36, is significant. The effect of this is not reflected in the calculations performed to analyze the level of royalties up to this point.

To fully appreciate the impact of the linkage, the provisions of section 36 of the Income Tax Act are discussed briefly. Section 15(a) of the Income Tax Act allows a deduction in respect of capital expenditure in terms of section 36. Section 36 defines capital expenditure to include expenditure in respect of shaft sinking, mine equipment, mine development, certain mining infrastructure (such as employee residences) as well as any expenditure incurred in terms of a mining right pursuant to the MPRDA. Capital expenditure is fully deductible from income derived from mining operations. The capital expenditure which exceeds the taxable income from mining operations (referred to as unredeemed capital expenditure) is carried forward and is deductible against income derived from mining operations in subsequent years of assessment. In a recent case heard in the Johannesburg Tax Court ${ }^{5}$ dealing with the application of section 36 the judge made mention of the fact that this provision was inserted in the Income Tax Act to provide a concession to mining companies to fully reduce their profits by their capital expenditure and in this manner not pay tax on their profits derived from mining for a number of years. The acceleration of the allowance for capital expenditure was intended to encourage the opening of new mines.

\footnotetext{
${ }^{3}$ Royalties imposed in terms of the MPRRA are deductible for corporate income tax purposes.

${ }^{4}$ This effective tax rate is calculated on profit of 100 as income tax at $28 \%(100 \times 28 \%=28)$ and dividends tax of 10,8 at a rate of $15 \%$ of the remaining 72 is distributed $(72 \times 15 \%=10,8)$.

${ }^{5}$ Tax Court Case Number 12856, which was subsequently heard in the Supreme Court of Appeal in Armgold/Harmony Freegold Joint Venture v CSARS (703/2011) [2012] ZASCA 152 (1October 2012).
} 
As EBIT is determined with reference to deductions allowed in terms of the Income Tax Act, the accelerated depreciation in respect of capital expenditure contained in section 36 of the Income Tax Act is carried over into the royalty regime. The impact of the application of this accelerated depreciation allowance in determining the royalty amount is illustrated using the information in the hypothetical investment scenario ${ }^{6}$ set out in Table 2 .

Table 2: Hypothetical investment scenario to illustrate the impact of section 36 on the mineral royalty

\begin{tabular}{|l|c|}
\hline $\begin{array}{l}\text { Capital expenditure to develop the mineral resource reserve (qualifies as capital expenditure in terms of } \\
\text { section 36) }\end{array}$ & ZAR10 million \\
\hline Life of mine & 20 years \\
\hline $\begin{array}{l}\text { Annual income derived from the sale and transfer of refined mineral resources (ignoring the effect of } \\
\text { inflation) }\end{array}$ & ZAR3 million \\
\hline Annual operating expenditure (ignoring the effect of inflation) & (ZAR1,6 million) \\
\hline $\begin{array}{l}\text { Annual accounting profit (assuming the capital expenditure is depreciated over the life of the mine for } \\
\text { accounting purposes) }\end{array}$ & ZAR0,9 million \\
\hline
\end{tabular}

Information on the royalties determined in accordance with the MPRRA based on the information in Table 2 is depicted in Graph 1 below:

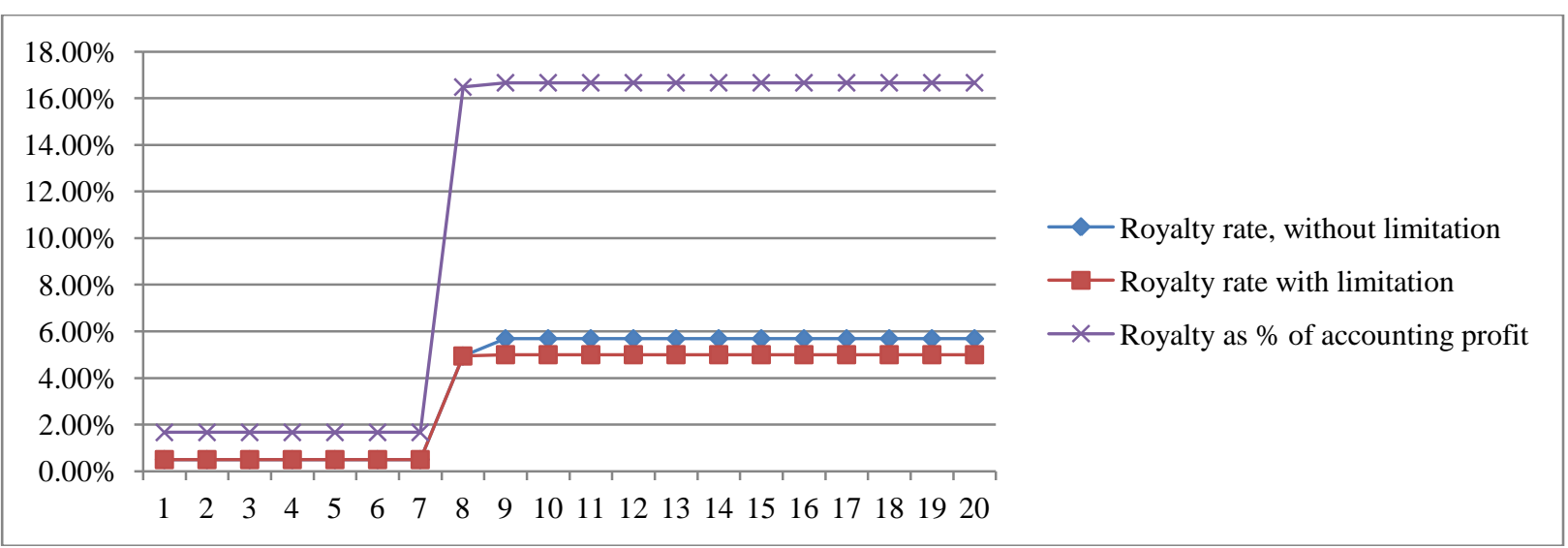

Graph 1: Royalties calculated based on the hypothetical investment scenario provided in Table 2.

This graph illustrate that the royalties are likely to only be calculated at a rate of $0.5 \%$ of the gross sales value of the minerals transferred while a company has a balance of unredeemed capital expenditure remaining for income tax purposes. At the point when the balance of the capital expenditure has been reduced to zero (during year 8 in the hypothetical investment scenario) the EBIT input into the royalty calculation increases significantly as it no longer reflects any deduction in respect of the initial capital expenditure. The results in Graph 1 indicate that this increase could be so significant that the royalty rate increases to a level where the cap on the royalty rate takes effect (as shown by the diamond line that represents the royalty that would have been charged had it not been for the maximum royalty rate compared to the square line which represents the capped royalty rate in Graph 1).

An important observation can be made from the results reported in Graph 1 about the impact of the linkage of EBIT for royalty purposes to section 36 of the Income Tax Act. The initial level royalties received by the State is at the minimum level while the entity has capital expenditure available for deduction. Once the full amount of capital expenditure has been deducted for income tax purposes, the level of royalties should show a sharp increase. As the purpose of royalties is to provide the owner of the mineral resource with compensation for the depletion of the non-renewable resource, it is submitted that the pattern of the distribution of royalties to the State does not reflect the pattern of depletion of the non-renewable resource (which was an even depletion pattern in the hypothetical investment scenario). As the State only starts receiving its share of the wealth further into the life of the project the effect of time value of money dilutes the value of the State's share of the rent from its mineral resources. In addition, the mismatch between the pattern of the depletion of the mineral resources and the pattern of the royalty

${ }^{6}$ ZAR represents South African Rand. 
payments created by the accelerated deduction of capital expenditure results in the cap on the royalty rate taking effect in circumstances that may not be extraordinary, which further reduces the State's share of the mineral wealth.

As the linkage of the royalty formula with the provisions of the Income Tax Act arises from the use of EBIT in calculating the royalty, it is necessary to consider the background for the introduction of EBIT into the royalty regime to be able to make a recommendation in this regard. According to National Treasury (2008a) the royalty formula was designed to ensure that the State share in both the upside when a commodity price boom takes place but also in the downside risk when the mining operations in which the minerals are extracted become less profitable. In order to link the royalty payable to the profitability of the extractor, and therefore the ability of the extractor to pay the royalty, the royalty rate was linked to EBIT of the extractor, as a profitability indicator. In the third draft royalty bill, it was proposed that EBITDA as determined for accounting purposes would be an appropriate indicator of profitability (South Africa, 2007). This proposal was however rejected due to the lack of a clear definition of EBITDA in terms of the International Financial Reporting Standards (IFRS) as well as the effect that accounting policy choices could have on the determination of EBITDA (National Treasury, 2008a). Similar concerns existed in respect of EBIT as those raised in relation to EBITDA. The legislation therefore resorted to other tax legislation (Income Tax Act) as a basis for determining EBIT. The trend in Graph 1 shows that the distribution of the royalties payable in relation to accounting profits (which may be a more accurate reflection of the extractor's ability to pay the royalty than taxable income) is similarly skewed and is not necessarily linked to the extractor's ability to pay the royalty during the period (in the hypothetical investment scenario, the ability to pay the royalty remained consistent, yet the royalty amount was not distributed evenly) while the extractor has an unredeemed capital expenditure balance. The reason for this distortion lies in the fact that the deductions allowed for income tax purposes, in particular the accelerated capital expenditure allowance, were not intended to be an indicator of profitability in all instances. Some of the deductions were in fact aimed at providing incentives to attract investors to new mining projects.

Based on these observations, it is submitted that EBIT, as determined with reference to deductions in terms of the Income Tax Act, does not result in a royalty that truly reflects the depletion of the mineral resources or the ability of the extractor to pay the royalty. The current definition of EBIT could furthermore deny the State the opportunity to share in the upside of commodity booms once the capital expenditure has been fully deducted as the cap on the royalty rate may be triggered due to the fact that no deduction is made in respect of capital expenditure later into the life of the mine. It is submitted that these shortcomings of the royalty regime can be remedied by defining EBIT specifically for the purpose of determining the royalties payable without reference to the Income Tax Act.

\section{Impact of the royalties on downstream beneficiation}

The royalty formulas in the MPRRA acknowledge the fact that downstream beneficiation increases the gross sales value of minerals at the time of transfer, which could result in an increased royalty being payable merely because the mineral resource has been refined. In an attempt to prevent this increase in the royalty payable due to the fact that the mineral resource had been refined, the MPRRA provides separate royalty rates for refined and unrefined mineral resources. As the B-factor (denominator) is a greater number in the refined rate formula (12.5) than in the unrefined rate formula (9), the royalty rate in respect of an unrefined mineral resource should be greater than that applicable to a refined mineral resource to compensate for the increase in the tax base due to beneficiation. Prior to the implementation of the MPRRA, Van der Zwan and Nel (2010) concluded that this measure may not be effective in negating the effect of an increased gross sales value if the increase in either the gross sales value or profitability of the extractor (EBIT) (or a combination of these inputs) is greater than the relative decrease in the B-factor from 12.5 to 9. Cawood (2011) also recognized that there would be a critical point where the royalty rate formulas may result in a higher royalty if a mineral resource is refined than when that same mineral resource is transferred in the unrefined condition which may discourage value addition in these circumstances.

As the MPRRA however imposes the royalty on an extractor at the point of transfer and contains a comprehensive set out transfer pricing rules to ensure that the gross sales value is determined as an arm's length value, an extractor who would be subject to a higher royalty on the transfer of the refined mineral resource than it would be on the unrefined mineral resource could structure its operations in a manner to avoid this. If the unrefined 
mineral is transferred by the extractor at an arm's length price to a related entity that refines the mineral, this should result in the royalty being imposed on the transfer of an unrefined mineral, even though refinement can still be done within South Africa and perhaps even by the same group of entities as the extractor. It is therefore submitted that even though the royalty formulas may in some cases result in a higher royalty on a refined mineral resource than the same mineral resource prior to refinement; this should not result in an insurmountable obstacle preventing or deterring value addition to mineral resources in South Africa prior to exporting it.

\section{Utilization of the royalties collected}

Otto et al. (2006) warns against populist calls for increases in mining tax (including royalties), in particular debates framed around political agendas. The level of royalties collected in terms of the MPRRA appear to be relatively high as evidenced by the earlier discussion, even though the linkage of the regime to income tax deductions may ultimately reduce the value of the State's share of the country's mineral wealth. Bird, MarquesVazquez and Torgler (2008) put forward the view that the political equilibrium of a country is often affected not only by whether the levels of tax collected are sufficient but also by factors such as voice, accountability and perceived corruption. As the mineral royalties are collected by the State as custodian of the benefit of South Africa's mineral wealth on behalf of all the people of the nation in terms of the MPRDA collected, these royalties may be perceived as instruments that should ultimately bring about socio-economic changes as suggested by Otto et al. (2006). It is therefore suggested that the calls for nationalization of the mining industry may not have arisen from the fact that the compensation collected for the depletion of the nation's mineral resources is not sufficient, but perhaps rather by the lack of accountability towards the nation about the utilization of the royalties for their benefit, as contemplated by Bird, Marques-Vazquez and Torgler. It is submitted that measures to improve the accountability regarding the royalties collected, rather than to increase the level of royalties, may improve the regime as far as meeting the objectives of the nation and the communities are concerned.

The MPRRA does not contain any provisions specifically aimed at accountability towards the nation as to how the royalties collected are utilized. Across the globe, measures such as direct distribution of certain royalties to affected regions and beneficiaries in Brazil (Postali, 2009), reporting of detailed information relating to the utilization of royalties collected in Alberta (Canada) and Norway (Tsalik, 2004) as well as ring-fencing of the revenue collected in a separate fund to be used for specific purposes ensure State accountability in respect of revenue collected.

At present, section 2 of the MPRRA states that the mineral royalties are collected for the benefit of the National Revenue Fund. This means that the royalties collected are pooled with other tax revenues and distributed as part of the annual national budgeting process. As a result perceptions and concerns regarding a lack of accountability by the South African government, such a those expressed by Aliber (2003), may extend to the mining industry and the perception of the nation about the benefits flowing from its share of the wealth from this industry. This fact has been identified in the SIMS report (ANC, 2012), which proposes the creation of a sovereign wealth fund using the proceeds from the proposed mineral taxes. It is proposed that this fund should be used to develop infrastructure, skills and geo-knowledge. Davis, Ossowski, Daniel and Barnett (2001) however point out that the mere creation of a wealth fund does not resolve the problem of a lack of accountability. Transparency and governance measures in respect of expenditure from these funds are of critical importance. The creation of a mineral resource wealth fund may be part of the process to manage the perceptions of the nation regarding the benefits obtained from the country's mineral wealth, but further research must be performed on the design and governance measures in relation to such a fund.

Based on the high level overview of possible instruments available to manage the State's accountability provided in this section of the article, it is recommended that measures other than the creation of a sovereign wealth fund as suggested in the SIMS report also need to be considered as tools to manage the perception and ensure that the optimal utilization of the nation's mineral wealth on behalf of all the people of the nation. 


\section{CONCLUSION AND RECOMMENDATIONS}

The South African mining landscape has changed significantly over the past twenty years. This change included the State obtaining custodianship over the nation's mineral resources and imposing a royalty as compensation for the depletion of these mineral resources. Despite these changes, calls for nationalization of the mining industry have been made suggesting that the nation may be not collecting a sufficient portion of the mineral wealth or that the benefits of the industry are not enjoyed by all South Africans. This prompted the research question posed in this article, namely to evaluate whether the South African mineral royalty regime effectively balances the objectives of the stakeholders in the mining industry and whether there are any aspects of this regime that can be improved to address the concerns resulting in calls for nationalization of the industry.

Based on objectives of the relevant stakeholders as identified and the analysis of certain aspects of the MPRRA, the following recommendations are made in respect of the South African royalty regime:

- $\quad$ The introduction of the royalty regime in terms of the MPRRA increased the government take from mining operations by an estimated $15,8 \%$. It is recommended that a comparison of the South African government take in respect of mining operations to that of countries with similar mineral resource wealth should be undertaken to establish whether that the tax regime is comparable and competitive with similar investment destinations.

- $\quad$ The linkage between the royalty formulas and the income tax legislation (in particular, the accelerated capital expenditure allowance in section 36) may result in royalties that do not reflect the depletion of the mineral resources or the ability of the extractor to pay the royalty. The distribution of royalties may also deny the State the opportunity to share in the upside of commodity booms later in the life of a project. It is submitted that these shortcomings of the royalty regime can be remedied by defining EBIT purpose of determining the royalties payable without reference to the Income Tax Act.

- The current royalty regime does not contain provisions dealing with accountability towards the nation as to the utilization of the royalties collected. This may contribute to the perception that the nation does not share in the country's mineral wealth sufficiently. It is recommended that further research needs to be conducted on measures that can be implemented to improve accountability over the royalties collected and demonstrate the benefits of the country's mineral wealth to the nation.

\section{AUTHOR INFORMATION}

Pieter van der Zwan is an associate professor and the Taxation program leader at the North-West University in South Africa. He is a Chartered Accountant and holds the CA(SA) designation. Postal Address: Postnet Suite 231, Private Bag x 1288, Noordbrug, Potchefstroom, 2520, South Africa. E-mail: pieter.vanderzwan@nwu.ac.za

\section{REFERENCES}

1. ANC. (2012). Maximising the Developmental Impact of the People's Mineral Assets: State Intervention in the Minerals Sector (SIMS). Retrieved from: http://anc.org.za/docs/discus/2012/sims.pdf

2. ANCYL. (2010). Towards the transfer of mineral wealth to the ownership of the people as a whole: a perspective on the nationalization of mines. Retrieved from: http://uscdn.creamermedia.co.za/assets/articles/attachments/25571 nationalisation of mines documentfeb_2010.pdf

3. ANCYL. (2011). ANC Youth League Constitution. Retrieved from: http://www.ancyl.org.za/docs/const/2011/constitutionh.pdf

4. $\quad$ Andrews-Speed, P \& Rogers, C.D. (1999). Mining taxation issues for the future. Resources Policy 25: 221227.

5. Bird, R.M., Martinez-Vazquez, J. \& Torgler, B. (2008). Tax Effort in Developing Countries and High Income Countries: The Impact of Corruption, Voice and Accountability. Economic Analysis \& Policy. 38(1) 55- 71. 
6. Cawood, F.T. \& Minnitt, R.C.A. (1998). A historical perspective on the economics of the ownership of mineral rights ownership. The Journal of The South African Institute of Mining and Metallurgy. (November/December 1998) 369 - 376.

7. Cawood, F.T. (2010). The South African mineral and petroleum resources royalty act - Background and fundamental principles. Resources Policy. (35) 199 - 209.

8. Cawood, F.T. (2011). An investigation of the potential impact of the New South African Mineral and Petroleum Resources Royalty Act. The Journal of The South African Institute of Mining and Metallurgy. (111) $443-453$.

9. Davis, J., Ossowski, R., Daniel, J., Barnett, S. (2001). Oil Funds: Problems Posing as Solutions? Finance \& Development. 38(4).

10. Eads, C., Mitchell, P. \& Paris, F. (2009). Advancing the EITI in the mining sector. EITI.

11. Janse van Vuuren, A. (2012). MPRDA review proceeds without Sims input. Miningmx. Retrieved at: http://www.miningmx.com/page/news/markets/1259344-MPRDA-review-proceeds-without-Sims-input

12. National Treasury. (2008a). Response document: Portfolio Committee on Finance, Mineral and Petroleum Resource Royalty Bill.

13. National Treasury. (2008b). Explanatory memorandum for the Mineral and Petroleum Resources Royalty Bill, 2008.

14. National Treasury. (2008c). Media statement: Mineral and Petroleum Resources Royalty Bills (Money Bill and Administration Bill), $4^{\text {th }}$ and final draft. Press statement issued on Tuesday, 3 June 2008.

15. Otto, J., Andrews, C., Cawood, F., Doggett, M., Guj, P., Stermole, F., Stermole, J. \& Tilton J. (2006). Mining royalties: A global study of their impact on investors, government and civil society. Washington D.C.: The World Bank.

16. Osmundsen, P. (1998). Dynamic Taxation of Non-renewable Natural Resources under Asymmetric Information about Reserves. The Canadian Journal of Economics. 31(4) 933 - 951.

17. Otto, J., Cordes, J. (2002). The Regulation of Mineral Enterprises: A Global Perspective on Economics, Law and Policy. Rocky Mountain Mineral Law Foundation, Westminster, CO.

18. Postali, F.A.S. (2009). Petroleum royalties and regional development in Brazil: The economic growth of recipient towns. Resources Policy. (34) 205-213.

19. Reuters. (2012). No surprises for mines - Manuel. Business Report, (6 February 2012). Retrieved at: http://www.iol.co.za/business/business-news/no-surprises-for-mines-manuel-1.1228480

20. Sharma. J.V.M \& Naresh, G. 2001. Mineral taxation around the world: Trends and issues. Asia-Pacific Tax Bulletin. January 2001: $2-10$.

21. South Africa. (2007). Draft Mineral and Petroleum Resources Royalty Bill.

22. South Africa. (2012) Income Tax Act, No. 58 of 1962. Last updated by Government Gazette, 423 (35396).

23. South Africa. (2002). Mineral and Petroleum Resources Development Act, No. 28 of 2002. Government Gazette, 448(23922):1-122.

24. South Africa. (2008). Mineral and Petroleum Resources Royalty Act, No 28 of 2008. Government Gazette, 521(31635):1-13.

25. Tsalik, S. (2004). Caspian Oil Windfalls: Who will benefit?. New York: Open Society Institute.

26. Van der Zwan, P., Nel, P. (2010). The impact of the Minerals and Petroleum Resources Royalty Act on the South African Mining industry: A critical analysis. Meditari. 18(2) 89 - 103. 


\section{$\underline{\text { NOTES }}$}

